\title{
Spivakian Concepts of Essentialism and Imperialism in Gabriel Garcia's "The Autumn of the Patriarch"
}

\author{
Mohammad Motamedi \\ Golestan University, Gorgan, Iran.
}

Abdolbaqi Rezaei Talarposhti
Golestan University,Gorgan, Iran.

Behzad Pourqarib

Golestan University,Gorgan, Iran.

White men are saving brown women from brown men. GayatriSpivak, "Can the Subaltern Speak?"

\section{Introduction}

Essentialism has emerged as a key concept in post-colonial literature. Several Critics have defined this term. "Essentialism is the assumption that groups, categories or classes of objects have one or several defining features exclusive to all members of that category" (Ashcroft et al. 73). On the other hand Essentialism is the perspectivewhich considers a set of attributes for any entity which forms its identity and meaning (Catwright 1968). Essentialism involves different aspects of life, politicaland cultural. In political manner it is defending the rights of margins of society in which Spivak calls them "other". Ashcroft et al. defines its purpose "to expose the falsity of this mode of representing the colonial subject as an "other" to the Self of the dominant colonial culture" (74). In cultural aspect it is necessary for those who are under the pressure and oppression.

Cultural essentialism, which is theoretically questionable, may be adopted as a strategic political position in the struggle against imperial power. Clearly, certain kinds of practices are peculiar to one culture and not to others, and these may serve as important identifiers and become the means by which those cultures can resist oppression and oppose homogenization by global forces. (Ashcroft et al. 17) 
A theorist like Gayatri Spivak concentrates on the dangers of counting that it was a simple issue to allow the subalterns to express themselves, "without knowing that their essential subjectivity had been and still was constrained by the discourses within which they were constructed as subaltern" (74).Gayatri Spivak describes essentialism in her own view, it refers to a plan that nationalities, cultural groups or marginal groups can use to present themselves and calls it Strategic Essentialism. They may have various differences but they engage in continuous debates, it is sometimes beneficial for them to in an impermanent manner using essentialism to bring forward their group identity in a simplified way to achieve definite goals, or to oppose the leveling impact of global culture (Ashcroft et al. 2010).

The term Essentialism in post-colonialism is almost discussed together with such classified questions like race and nation. On the other side, at a more realistic level, "essentialist practices and modes of representation have been applied by groups and individuals in the promotion of certain minority rights or demands (as well as liberation struggles)" (Eide 4). There is a link between essentialism and classification of the society into superior and inferior. The inferior group consequently tries to define itself by its own standards.

In post-colonialism there is a close connection between Imperialism and strategic essentialism.Imperialism is one of the major aspects of post-colonial studies that caused different theorists to have study on it. GayatriSpivak is one of those theorists who worked on it seriously and examined it in various aspects as she says "in the current stage of "capitalism being transformed into imperialism,"globalization in trade and finance capital the native informant's foreclosed perspective is located in woman's global subalternity, the computing of the great narrative of history by the shifting currents of global imperialism seem more apposite (A Critique of Postcolonial Reason 89). The Imperialism also divides the society into two groups one is the ruling class the other is the inferiors or otherness of Spivak who are suppressed by the oppression of the first class.

Literature as a tool can show the depth of oppressions of those who consider themselves superior, the inferiority and suppressions of the margins all through the similar context and characters. After Colonialism many writers tried to show the tyranny of the rulers to the world in order to be heard. Gabriel Garcia Marquez is one of the Post-colonial writers who skillfully showed the oppressions of the tyrant ruler of Caribbean Sea who stands as the symbol of other tyrants around the world.

It is important to note that “Gabriel García Márquez's speech broadcast an indignant postcolonial protest to a world that was just beginning to recognize the marked problems of colonial and imperialistic aftermath" (Mishina 112). When 
Marquez awarded a noble prize, he had an objection to the post colonialism which shows his central political believe; European colonial ventures and AngloAmerican imperialistic enterprises forced on Latin America a reversal of the history that Latin America should have had a history like this. This reversed history reproduces fierce patterns of hostility between anti-colonial groups and those who have spread the colonial patterns as privilege. The enduring and "volatile polarization" that has produced out of this harsh duality of the anti-colonial viewpoint versus the colonial one clarifies much of the fierce history of García Márquez's Colombia. (112)

In this paper, we have tried to study The Autumn of the Patriarch (1975) by Gabriel Garcia Marquezin the light of Spivakian theories of Essentialism and Imperialism. Amongst all of his works this work is mainly about power, oppression and suppression of margins. Gabriel Garcíaexplain the plot in this way:

My intention was always to make a synthesis of all the Latin American dictators, but especially those from the Caribbean. Nevertheless, the personality of Juan Vicente Gomez [of Venezuela] was so strong, in addition to the fact that he exercised a special fascination over me, that undoubtedly the Patriarch has much more of him than anyone else. (Williams 111)

The Autumn of the Patriarch is not thoroughly written based on reality and documented of South America and more precisely Latin America. Unlike Alain Resnais's Night and Fog which is obsessed with sufferings and torture, Garcia Marquez cover various things based on reality not based on depicting an illusionary world and images and also he advocates the rightness among people. "This novel is both a political novel which scrutinizes the source and organization of dictatorship." (AlokBhalla 1597)

We scrutinize the way author deals with essentialism of common people and Imperialistic atmosphere of a country on the Caribbean Sea in South America. The Autumn of the Patriarch is entirely a historical book. Gabriel Garcia believes that the responsibility of the novelist and journalist is to learn about odds out of reality, and it is also the task of the prophet (The Art of Fiction 1981). This novel shows the mortifying effects of power. Moreover, it focuses on a tyrant dictator who is completely similar to all horrible dictators who came to power all around the world after the end of colonialism. Various postcolonial themes are trace able like essentialism, otherness, capitalism and oppression. 


\section{Discussion}

Gabriel Garcia skillfully describes the General who is the major character in the Autumn of the Patriarch. The whole story moves around this character, his orders, and in simple term all he does.Thetyrant ruler of a country on the Caribbean Sea in South America, the General, is deceased and his fortress is attacked.The narrator recalls about the life and the reign of the General in a long series of wars, known as the Federalist wars then the General becomes the ruler of the state.Moreoverhe is the leader of liberal's party and came to power with the help of the Navy of Britain. Years latertheAmerican marines occupy the state and lastly leave. The occupiers leave the nation since they are afraid of prevalent disease which was told to be widespread in the nation.

The General's mother, Bendicion Alvarado dies, and General ordered to display her body around the nation. The General wants her mother to be considered as a saint. In spite of the General's all effort, the representatives of the pope rejects this demand and in return the General expels all the Catholic clergy from the country. The General observes a young nun, Leticia Nazareno, as she is ousted. General orders to kidnap her and then she becomes the General's lover, and the wife and mother of his only legitimate child, Emanuel. Leticia wants General to bring back the pop's representative and the church, but later on Leticia becomes more and more avid and also she brings her greedy family to the state. Eventually, Leticia and her son are murdered.

The General become old and frail, but still wants to get revenge on members of his High Command and other plotters in the killings. Eventually, the General employs a torturer and assassin from the old feudal government, Jose Ignacio Saenz de la Barra. Then the General build a new civilian state. Now the General is very old and wants to play various sexual and other games, like abusing school girls His last displeasurewas that he was obliged to sell the Caribbean Sea.At last the General dies, and the crowd invades the fortress. The people party the ending of his reign (Bookrags 2016).

\section{1. Essentialism and Women as Subalterns}

Gayatri Spivak describes essentialism in her own view, it refers to a plan that nationalities, cultural groups or marginal groups can use to present themselves. They may have various differencesbut they engage in continuous debates, it is sometimes beneficial for them to in an impermanent manner using essentialism to bring forward their group identity in a simplified way to achieve definite goals, or 
to oppose the leveling impact of global culture (Ashcroft et al. 2010). So it is obvious that strategic Essentialism occurs when there are two groups, one is superior and the other one is inferior. In such society those who are inferiors should use some strategies in order to get rid of being called other or inferior. Thus the term Essentialism is a general word which has otherness, subalternity which is specifically marginalization of women in society and also Strategic Essentialism.

In 1985 Spivak declared, particularly in her accounts of the double subjection of colonized women and her discussion of the quieting of the muted native subject, in the form of the subaltern woman, has testified to the fact that there is not any spacefor the subaltern to express themselves. Byallegation, the quieting of the subaltern woman ranges to the entire of the colonial domain, and to the quieting of all nations, both male and female (Ashcroft et al. 2007). Gayatri Spivakre established the feminist dissertation in her essay "Can the Subaltern Speak?" In this essay, Spivak focuses on the problems and complications of Women in the Third World. These women have never been stated in the global context. Spivak's text smirrored the background of the effort and oppression of women in the Third World Countries. There are localvariances everywhere and the history that has played animportant role in their creation should be examined more effectively. (Gayatri Spivak1987)

In this novel women are almost treated as a sex tool and they are raped by the main character, General. Except two women, Bendición Alvarado who was mother of General and Leticia Nazareno his legitimate wife, other women are treated badly.At different parts of the novel it is vivid that women do not have any rights and any objection will be stopped by force.

... I gave you what no one has ever given anybody in this world even lending you my own women, although we'd best not talk about that general because it's better to be gelded by a mace than to go about laying mothers on the ground as if it were a matter of branding calves, just because those poor heartless bitch waifs don't even feel the brand or kick or twist or complain like calves,and they don't smoke from the haunches or smell of singed flesh which is the least one asks of good women, but they lay down their deadcow bodies so a person can do his duty while they go on peeling potatoes and shouting to the other women please keep an eye on the kitchen for me while I take a breather here so my rice doesn't burn, only you think that stuff like that is love general, because it's the only kind you know, without the least respect of course. . . .(The Autumn of the Patriarch 9) 
As it is mentioned in the novel, The General does not believe in the value of women and tell Patricio Aragones that I lend you my own women. At one part he also calls women that they are like branding calves since they do not feel anything and have no objection. He just respected her mother and said "... he proclaimed matriarch of the land by decree with the simple argument that there is no mother but one, mine, a strange woman of uncertain origins whose simpleness of soul had been the scandal of the fanatics of presidential dignity during the beginnings of the regime. .." (16).Although her mother does not have a genuine background; she believes her mother is the best woman. General always has a fear of death and tries to avoid it; he asks a fortuneteller to tell when he dies and just for his ambition he asks this question from a poor woman and when he hears that he is not going to die soon, he decides to kill the fortuneteller.

... and he asked if it was to be in a bad way or from a bad illness, and she answered himno, it was to be during his sleep and without pain, and he said aha, and he asked her trembling when it was to be and sheanswered him that he could sleep peacefully because it would not take place before you reach my age, which was 107, but also notafter 125 years more, and he said aha, and then he murdered the sick old woman in the hammock so that no one else would knowthe circumstances of his death, he strangled her with the strap from his gold spur, without pain, without a sigh, like a masterexecutioner, in spite of the fact that she was the only being in this world, human or animal, whom he did the honor of killing withhis own hand in peace or in war, poor woman ....(31)

As it is portrayed in the story, women cannot declare their opinion or in other words speak. Whenever they express themselves they have been suppressed badly. Contrasting to Spivak, Bhabha has declared that the 'subaltern' people can talk, and that a native expression can be regained. He introduced the notion of mimicry and parody, both as a technique of colonial domination by using reformation, regulation and discipline which seizes "appropriates" the Other', and the inapt imitations of natives in this case, which has the effect of threatening colonial authority which actually advises that the subaltern has spoken, and that correctly indicative analyses of the colonialist manuscript can and do "regain a native voice" (qtd. in Ashcroft et al.175-176).Gabriel Garcia Marquez tries to depict a tyrant General who suppress any objection while believes in no rights for women; $\mathrm{He}$ always tries to mock and abuse them. Marquez successfully depicted a character that is merciless in this case. 
. . . it's death, he thought, his tunic soaked with blood, before realizing no general sir, it was the hurricane, the most devastating of all those that had broken the ancient compact realm of the Caribbean up into a string of scattered islands, a catastrophe so stealthy that only he had detected it with his premonitory instinct long before the panic of dogs and hens began, and so quick that there was scarcely time to find a woman's name for it in the disorder of terrified officials who came to me with the news that now yes it was true general sir, this country had gone to hell. . . . (The Autumn of the Patriarch 33)

Here General refers to the catastrophe and disorders and declares they all happened so quick that he hadn't had enough time to choose a woman name for it; again here he mocks women and shows inferiority of them. As mentioned above Marquez by depicting a tyrant General as a ruler, successfully has shown that women didn't have a proper place in society as Spivak calls them Subaltern, who are marginalized and cannot express themselves.

Gabriel Garcia skillfully depicted women as subalterns; those who cannot express themselves and object and whenever any objection was seen, suppressed harshly. General didn't believe in value and place of women as human beings except his mother BendicionAlvarado and his only wife Leticia Nazareno. Spivak believes that in a post-colonial society women are considered as margins and calls them "subaltern" who cannot speak and declare themselves since they are inferiors in the masculine society.

\section{2.Common People as Otherness}

According to Spivak, the notion of the other is a general occurrence in which eachperson asserts to be the subject and all the rest would be categorized as the "Other". The concept of other is greatly relative and it may be varied within each context (Gayatri Spivak 1987). De Beauvoir expresses about the notion of the "other" in this way; the category of the other is as ancient as awareness itself. In the simplest civilizations, in the most antique mythologies, anybody can find this notion of dichotomy which is "Self" and the "Other". This dichotomy was not basically related to the division of the genders, it was not reliant on any experimental facts that Spivak says on behalf of Simone de Beauvoir "Otherness is a fundamental category of human thought"(qtd. in In other worlds 130).

The notion of the other includes both the women of the third world and all the unwanted people like those who are inferior, mentally underdeveloped and people with homosexual activities. The "other" always includes a position out of the main- 
stream of life and those people are treated as lower who do not give anything to the benefit of the society (130).The first step to find the dependency is to find one's identity and believe in it. In the Autumn of the Patriarch common people and also other commanders do not believe in their rights as people of society. The reason was because of a tyrant ruler who was General. He suppressed any objection and behaved as an owner of people's life without treating them with respect:

... only you [General] think that stuff like that is love general, because it's the only kind you know, without the least respect of course, and then hebegan to roar shut up, God damn it, shut upor you'll pay for it, but Patricio Aragonés kept on saying without the slightest intention of a joke why should I shut up when all youcan do is kill me and you're already killing me, it would be better now to take advantage and look truth in the face general. . . (The Autumn of the Patriarch9)

Because The General is so tyrant nobody dared to say something which is against the idea of General, so they tried to keep their face in order to save their life, even that utterance was untrue. This kind of behavior come from where that Spivak calls them "Other" who cannot express themselves. The General just think about his benefits since other things are coming at second hand.

... I'll only keep the presidential guard who are straightshooters and brave fellows and I'm not going to name any cabinet, God damn it, just a good minister of health which is the onlything anyone really needs in life, and maybe another one with a good hand for what has to be put in writing, and that way we canrent out the ministries and barracks and save the money for help, because what's needed here isn't people but money. . . (11)

As we can see, the General just think about his benefits and just wants to save his money without any consideration, if he wants to employ a minister that would be minister of health since he was ill all the time, he needed someone to look after him and the money is the most important factor for his decision making.Common people who are considered as other are shown; the term of other by Spivak considers all people who are inferiors in society. It is more general than the term of subaltern which is dedicated to the inferiority of women in society. Gabriel Garcia depicted the life of common people and misuse of those people. General as tyrant ruler considers himself as superior and all other people are categorized as inferiors of society or others. 


\section{3. Strategic Essentialism}

Strategic essentialism is an attitude established by Gayatri Chakravorty Spivak, which defines the political use of what is considered to be an "essence" with a critique and recognition of the essentialist nature of the essence itself. This concept operates in relationship to the concept of the subaltern. The "subaltern" is a term often used to represent the oppressed or "other" in society and Spivak recognizes that what constitutes the subaltern is defined by the elites. (qtd. in Ritzer and Rayan $619)$.

One of the major criticisms of strategic essentialism is that people who are considered as "others" should come to this power and reach to certain level of independency to express themselves, to speak and to show their objection against tyranny and injustice. In this novel people are passive and obey whatever the General orders moreover during the course of the story the General humiliate people by his ridiculous commands as he says ". . . the clock in the tower should not strike twelve at twelve o'clock but two times so that life would seem longer, the order was carried out, without an instant of hesitation, without a pause. . .."(The Autumn of the Patriarch 3)

Changing the time is the most bizarre element in this novel that Garcia Marquez elaborated as he wanted to show the complete dominance of the General on people's life. Later on people came to this idea to believe themselves, to temporarily use essentialism and to introduce their common identity in an easy way to attain certain goals. One of those ways is planning to kill the General; that was the first rebellion against tyranny of the General.

... and he [the General] was the only one who spotted the evil omen, and he sensed that it was so clear and so imminent that he secretly ordered his escort to arrest one of the musicians, that one, the one playing the tuba, and, indeed, they found a sawed-off shotgun on him and under torture he confessed that he had planned to shoot him during the confusion as the people left, it was quite obvious, of course, he explained, because I was looking at everybody and everybody was looking back at me, but the only one who didn't dare look at me one single time was that son of a bitch with the tuba....(7)

As Marquez showed thatwasthe first conspiracy against the General; in this way he came to this idea that he needs more protection because people going to have rebel against him. By this action people understand that they can take the serenity from him. After that People decided to express their voice through rebel and shouting. 
... they were shouting out the words on them from the balconies, from memory they repeated down with oppression, they shouted death to the tyrant, and even the sentries along the corridors of the presidential palace were reading aloud about the union of all without distinction of class against the despotism of centuries, patriotic reconciliation against the corruption and the arrogance of the military, no more blood, they shouted, no more pillaging, the whole country was awakening from its age-old sleep at the moment he was going through the coach house door and he ran into the terrible news general sir that Patricio Aragonés had been fatally wounded by a poisoned dart. (8)

If we assume the deeds of characters like Aragones or in more general aspect we consider people as rebels against the Generals power, with our awareness that power is diffused and "wherever there is power there is resistance" (Foucault67) and as Garcia showed in above paragraph we see that people of the story put up a kind of resistance against the corrupted socio-political and economic order in tyrant society. Garcia's the Autumn of the Patriarch, presents all people as subalterns, some of them try to bring about change through resistance like Aragones. But as subalterns they do not have the clear voice to stand for it as their rights. These people resist against both local and global discriminations. Most of the events in the Autumn of the Patriarch are related with historical events.

The idea of strategic essentialism involves philosophical reception of the antiessentialist dispute that there are in beliefofno essential identities while nevertheless telling that in practice people act, and need to act, as if there were. "Thus strategic essentialism means acting "as if" identities were stable for specific political reasons. For example, one might temporarily accept the category of "woman" as a stable unity for the purpose of mobilizing women for political action" (qtd. in Spivak: In Other Words110).Because "Spivak insists on revealing that the one can no longer imagine a formal script of ethical responsibility based on knowing the other without noting one's sense of complicity precisely in the very script that produces the other" (qtd.in Ray 57) and in 2008 we see Spivak express it in this way,"(thinking of) responsibility is also the (thinking of) contamination" (Other Asias61). In the Autumn of the Patriarch one of the major characters who tries to show his dissatisfaction at General is Patricio Aragones, his perfect double; he shows it by expressing his real feeling and talking at the bottom of his heart. This character came to this point to express his rebellion when he was about to dye, if he could stand against the tyranny of General earlier he didn't have to tolerate different tortures and disasters. Garcia shows it through dialogues between General and Patricio Aragones: 
He stayed with him during his slow agony, the two of them alone in the room, giving him the spoonfuls of anodyne with his own hand, and Patricio Aragonés took them without gratitude telling him between spoonful I will leave you here for a while my general with your world of shit because my heart tells me that quite soon we shall meet again in the depths of hell, I all twisted up worse than a mullet because of this poison and you with your head in your hand looking for a place to put it, let it be said without the least bit of respect general sir, that I can tell you now that I never loved you as you think but that ever since the days of the filibusters when I had the evil misfortune to chance into your domains I've been praying that you would be killed, in a good way even, so that you would pay me back for this life of an orphan you gave me, first by flattening my feet with tamping hands so that they would be those of a sleepwalker like yours, then by piercing my nuts with a shoemaker's awl so I would develop a rupture, then by making me drink turpentine so I would forget how to read and write after all the work it took my mother to teach me. . (The Autumn of the Patriarch 9)

Above sentences shows how poor Aragones was, since he tolerated all those tortures like flattering feet, piercing of nuts, drinking of turpentine and so on. "Most people who use (essentialism) use it as a slur word, intending to put down the opposition" (qtd. in Phillips 2); moreover this character is used as a sample for those who have to use strategic essentialism to establish their identity. "When this happens, the identity is being defined by reference to an essential defining characteristic, and those who do not fit are in trouble" (20).

After the death of General's double, Patricio Aragones, the whole country went to despondency. That was the time for General to see the reactions of people who thought that he is dead. From the point that people at that time were completely dependent upon the General, they didn't believe in their own identity and their independency and in Spivak's explanation strategic essentialism, so they felt a great depression since they couldn't imagine the situation without a leader.

. . . he [General] saw a schoolgirl who laid a flower on him[Aragones], he saw a fish wife who could not resist the truth of his death and strewed her basket of fresh fish all over the floor and embraced the perfumed corpse sobbing aloud that it was him, my God, what's going to become of us without him. ... (The Autumn of the Patriarch 10) 
When people cannot take the control of their life, when they are unable to recognize their potentials, then in these situations they stuck and cannot see the world independency. "Spivak suggests that strategic essentialism champions essentialism even if it is not fully believed in because it is needed in the fighting of conflicts, intellectual arguments, and political battles. It can be useful shorthand" (qtd. in Ritzer and Ryan 193).

He did not have to take any of the predicted measures because the army broke up on its own, the troops scattered, the few officers who resisted until the last moments in the garrisons in the city and in another six in the countryside were wiped out by the presidential guards with the help of civilian volunteers, the surviving ministers fled into exile at dawn and only the two most faithful remained, one who was also his private physician and the other who had the best handwriting in the country. . . (The Autumn of the Patriarch 12)

Above sentences reveals the power of people that if they believe in themselves and use a strategy in order to express themselves they can be successful and get rid of the oppressions. "In an attempt to reassert the political force resident in her theory, Spivak spoke of the need to embrace a strategic essentialism, in an interview in which she acknowledged the usefulness of essentialist formulations in many struggles for liberation from the effects of colonial and neo-colonial oppression"(qtd. in Ashcroft et al. 74).

Lack of confidence and having passivity is another factor in this novel which caused people not to have a certain goal for themselves and for their country. One of the major reasons of creation of dictatorship government in this novel is passivity of its people who do not using essentialism and giving the control of the country to one tyrant person. In this novel people led everything to happen by fate:

... from the rust on their foghorns, they would go down to the harbor in the drizzle of early dawn in search of the newspapers the crewmen had used to wrap up the lunch they took ashore, they found them in the garbage cans and read them up and down and left to right down to the last lines to predict the future of their countries from the news of who had died, who had got married, who had invited whom and whom they had not invited to a birthday party, deciphering their destiny according to the direction of a providential storm cloud that was going to roar down on their country in an apocalyptic tempest that would overflow the rivers 
which would burst the dams that would devastate the fields and spread misery and plague in the cities. . (The Autumn of the Patriarch 13)

Gabriel Garcia skillfully shows that the fate of people who cannot defend their rights and express themselves and those who let everything to happen by its nature as destiny is like the life of people in the Autumn of the Patriarch. As a matter of fact the life of each person and the destiny of individuals make the public one if it is looked in a greater scope as "Whatever the merits of Jameson's claim that private experience is represented as allegorical of the public and national destiny, it has aroused considerable discussion regarding the nature of post-colonial allegory, the construction of three worlds, and a questioning of the importance given to the nation over other social formations in the experience of Third World cultures"(qtd.in Ashcroft et al. 140).

In different parts of the Autumn of the Patriarch Garcia depicts the General as horny and reckless character with women. Women are shown inferiors to the men, who do not have any right, no right for objection, no chance to express; they are looked just for their body. According to Spivak's essentialism, women should express themselves in order to take their rights.

Such prejudices were generated either for economic reasons or to control indigenous populations in colonial possessions by emphasizing their difference and constructing them as inferior ... the special role played by gender in constructing Images of colonial inferiority and in constructing a special 'double' colonization for women within the general field of colonial oppression. This has led to a greater concern with the body as a site for gendered readings of post-colonial subjectivity (qtd. in Ashcroft et.al. 166)

And can be scrutinized in women's realm or “women's issues" (Narayan 86).

It was calculated that in the course of his life he must have sired five thousand children, all seven-mothers, by the countless number of loveless beloveds he had who succeeded each other in his seraglio until the moment he was ready to enjoy them, but none bore his name or surname, except for the one he had by Leticia Nazareno, who was appointed a major general with jurisdiction and command at the moment of his birth, for he considered no one the son of anyone except his mother, and only her.(The Autumn of the Patriarch 16) 
General has many loveless beloved and keep them just for his pleasure and serving; in such situation the value of woman is lost, and injustice occurs. "Justice, in its many guises, is a fundamental principle ensuring order in social groups ranging from small, intimate circles of friends to large, diverse societies. Its counterpart, injustice, arises when expectations about distributions, procedures, or interactions are unmet" (Ritzer and Rayan 563).General himself is also dependent on occupiers who were Americans, the troops left the country because there was a rumor that plague is widespread in country, so they decided to leave; they also disrespected General and thought he couldn't manage the nation without their help:

. . . but before bearing off that portable paradise of war in their flying trains they decorated him with the medal of the good neighbor, rendered him the honors of chief of state, and said to him aloud so that everybody could hear we leave you now with your nigger whorehouse so let's see how you shape things up without us ...(The Autumn of the Patriarch 17)

One of the post-colonial aspects of this novel is dependency and racism; as demonstrated above the occupiers who know this fact that General is dependent on them, they used it and told him how do you want to control everything without us; the occupiers also considered black people inferior and used the word nigger which is a very offensive word for black person. "The usefulness of the concept of race in both establishing the innate superiority of imperial culture as it approached its zenith, and at the same time lumping together the inferior races under its control. . ." (Ashcroft et al. 183), in this case "Spivak continues to take to task modes of critical self-representation ..." (qtd. in Ray 3).

Many parts of the Autumn of the Patriarch shows lack of independence of women, they cannot express themselves and declare their thoughts since they are considered inferior.

... she [Manuela Sanchez] was alone, watched over in her most intimate aims, the captive of a trap of fate in which she did not have the courage to say no nor did she have sufficient courage to say yes to an abominable suitor who besieged her with a madhouse love, who looked at her with a kind of reverential stupor fanning himself with his white hat, drenched in sweat, so far removed from himself that she had wondered whether he really was looking at her or whether it was only a vision of horror, . . .(The Autumn of the Patriarch 26) 
Manuela Sanchez a widow whom the General fell in love with, was not sure about the love and his impetus, since General was a person who only thought about his benefits and pleasure. Manuela was not courageous enough to say no to General's proposal, this is lack of essentialism that Spivak wants everybody to have. Garcia Marquez wanted to demonstrate the unorganized situation of women in a dictatorship society where women are looked as a tool to supply their needs and they are going to be left alone or even being killed after that. According to Spivak, this inferiority should not keep them away from expressing and believing themselves. Like these parts:

... and then he [General] murdered the sick old woman in the hammock so that no one else would know the circumstances of his death. . . I [Poncio Daza] was dying with fear I maintained enough lucidity to realize that my only means of salvation was to let him do everything he wanted to with me on the dinner table ... while the man with the machete took Poncio Daza into the banana groves and cut him up into such thin slices that it was impossible to put his body back together again after it had been scattered by the hogs, poor man, but there was no other way out, he said, because he would have been a mortal enemy for the rest of his life. . . and so quick that there was scarcely time to find a woman's name for it in the disorder of terrified officials who came to me with the news that now yes it was true general sir. . .(31-33)

All above sentences are examples of inferiority of women where the General told the old woman to presage about his future and after listening, killed the poor woman, after that he seduced a young girl, then killed her, or in the last part chose a woman name for mocking all because they did.t try to believe themselves who have rights the same as men. "Gayatri Spivak famously wrote of a strategic essentialism that could invoke a collective category - like the subaltern or women" (qtd.in Phillips 2) and in more general form "Spivak identifies more generally in Anglo-American feminist discourse is that the female individualism posited by the essentialism is most often achieved at the expense of the other woman"(qtd. in Ray 113).

Strategic essentialism as the most important subdivision of essentialism is dominant in the Autumn of the Patriarch. After investigation of the terms "subaltern" and "other", Spivak declares "Strategic Essentialism" through which people who were inferiors of the society, could find their true identity and place in society. After different rebels and objection, people came to this idea that by 
uniting and believing in themselves, they can reach to the place where they belong. Through "strategic essentialism" people were successful to get rid of the occupiers.

\section{4.Imperialism}

Imperialism in its more new sense is the acquisition of an empire of overseas colonies came in three major waves: "the age of discovery during the fifteenth and sixteenth centuries; the age of mercantile Capitalism during the seventeenth and eighteenth centuries; and the age of imperialism inthe nineteenth and early twentieth centuries"(Ashcroft et al. 112). Then he adds "Hobson was explaining the economic emergence of late nineteenth-century imperialism, but the link between nation and expansion is much older - the emergence of the nation-state and the imperial-capitalist economies of post-Renaissance Europe being arguably inseparable" (qtd in. Ashcroft et al. 137).Spivak also believes "the lines of contact between imperialism and de-colonization on the one hand, and the march of global capitalism on the other [as constituting] the most encompassing crisis of narrative today ..." (Ray 99); moreover Spivak sees the only way of escaping from oppression as "Nationalismcan only ever be a crucial political agenda against oppression" (A Critique of Postcolonial Reasons 188)

\section{5. Oppression}

Another fundamental postcolonial theory in the play is oppression which is one of the subdivisions of imperialism in post-colonial studies. In the Autumn of the Patriarchit can be viewed in two aspects. One is the oppression of foreign occupiers on General and people and the second one is the oppression and tyranny of General on people and more specifically on women. "No perspective critical of imperialism can turn the Other into a self, because the project of imperialism has always already historically refracted what might have been the absolutely Other into a domesticated Other that consolidates the imperialist self" (Spivak 1985).

There is a dialogue between General and Patricio Aragones which shows an absolute tyranny of General; "only you [General] think that stuff like that is love general, because it's the only kind you know, without the least respect of course, and then he began to roar shut up, God damn it, shut up or you'll pay for it. .." (theAutumn of the Patriarch 9).Through this part Garcia Marques masterfully shows that any objection will be suppressed, so in this situation no one dares to object or tell the truth and all who were in contact with General told him what he wanted to hear. Garcia Marquez also shows some aspects of nationalism mixed with the notion of oppression which are both considered as post-colonial aspects of the novel. 
$\mathrm{He}[\mathrm{General}]$ did not have to take any of the predicted measures because the army broke up on its own, the troops scattered, the few officers who resisted until the last moments in the garrisons in the city and in another six in the countryside were wiped out by the presidential guards with the help of civilian volunteers . . . .(12)

When the oppression reached to its zenith, people decided to rebel and suppress the oppression and expel the occupiers. They showed if they unite against tyranny and oppression, they can defeat the enemy. For both women and those who are oppressed "partially integrated in a civilization that nevertheless regards them as constituting an inferior caste" (de Beauvoir 335).

Another form of oppression is revealed through General on his entourage. Garcia Marquez strikingly demonstrated the form of suffocating situation through time. General changes the time in a way he likes. This part of the novel shows the absolute tyranny and oppression of general.

It was hard to admit that that aged person [General] beyond repair was all that remained of a man whose power had been so great that once he asked what time is it and they[General's entourage] had answered him whatever you command general sir, and it was true, for not only did he alter the time of day as best suited his business but he would change legal holidays in accordance with his plans to cover the whole country from holiday to holiday in the shadow of the barefoot Indian and the mournful-looking senators and with the crates of splendid cocks who faced the bravest there were in every village square ... (The Autumn of the Patriarch 29).

"He has indeed changed time, the calendar, and altered the reality of his subjects in an effort to instill in them his own perceptions of reality. All of the excesses of power that were exercised with the individual double are now applied on a grander scale to the whole of society." (qtd.in Anadon 15).The misperception of the thought of the nation with the practice and power of the country creates nationalism one of the most influential forces in modern society. Furthermore it makes it particularly argumentative site, onwhich thoughts of "self-determination and freedom ofidentity and unity collide with ideas of suppression and force, of domination and exclusion."(Ashcroft et al. 136).

He [ General] booked the bets himself, he made the foundations of the cockpit shake with laughter because we all felt obliged to laugh when he gave off his strange snare-drum guffaws that rang out above the music and the rockets, we suffered when he was silent, 
we would break out in an ovation of relief when his birds struck ours with lightning ours having been so well trained to lose that not a single one let us down, except the cock of Dionisio Iguarán's misfortune who struck down the gray one belonging to the power in an attack so clean and sure that he was the first to cross the ring and shake the winner's hand. . . and he[ Dionisio Iguarán] went home to the applause of the excited people and the noise of the music and the petards showing everybody the six pedigreed cocks he had been given in exchange for the undefeated red one, but that night he locked himself up in his bedroom and drank a gourdful of cane liquor all by himself and hanged himself with the rope from his hammock, poor man. . .(The Autumn of the Patriarch 29)

As showed above General was a person who just wanted to be a winner at any cost, he chose the best cocks to win the match, and those who dares to win him would be killed silently; that amount of tyranny led people to be aware of the consequences of winning, so they decided to train their cocks lose instead of winning; except one who was Iguaran and after that competition he was so happy and drunk which led him to hang himself and if he wouldn't do that, General would have sent a killer to kill him silently.

... but he said no, the church is with the one in charge, he said, the generals of the high command having been meeting for forty-eight hours now already had not been able to reach an agreement, it doesn't matter he said, you'll see what they decide when they find out who pays them the most, the leaders of the civilian opposition have finally shown their faces and were conspiring openly in the street, all the better, he said, hang one from each lamppost on the main square so they'll know who the one is who can do anything . . . (39-40)

In each post-colonial society those who are inferiors are under the oppression of superiors. There is a tight relation between one's essentialism and not to be considered as inferior in other words "oppressed minorities" (qtd in Ray 99)."you'll [General's entourage] see, he said, they'll [occupiers] go back to dividing everything up among the priests, the gringos and the rich, and nothing for the poor, naturally, because they've always been so fucked up ..."(The Autumn of the Patriarch 55). Garcia shows again that poor people are inferior where the occupiers going to divide country between priests and rich. Till the very end of the novel, General as a symbol of tyranny and oppression think about himself, although he is about to die he says "I am the government after all" (70). So as 
showed above different forms of oppression, from the side of occupiers and also by General were applicable in the Autumn of the Patriarch.

Concluded indirectly about Oppression, in post-colonial societies, it was dominant, and can be considered as one of its major themes. The protagonist of the novel, General was shown as a symbol of tyranny and oppression that no one would have dared to object because the slightest objection were confronted and suppressed heavily and even could end with death of that person; at last but not least people united with each other and defeated General. By depiction of such character and resolution of the Autumn of the Patriarch Gabriel Garcia wanted to prove that by unity and believing in power of oneself which Spivak calls it essentialism, nations can conquer the oppressors.

\section{6. Capitalism}

Gabriel Garcia Marquez calls the Autumn of the Patriarch as his masterpiece in post-colonial works, so it is not unbelievable if we can apply different forms of post-colonial elements like capitalism which is one of the subdivisions of imperialism Gayatri Spivak on her post-colonial critic says"as much as capitalism becomes imperialism" (22) becomes displaced in a complete different ways. As General is from the ruling class, then other classes like middle or working are considered inferior, Spivakin 2014 argues "Class" differences that were formed were often inseparably tied up in racial, religious, and historical variance which, cannot purely be sidestepped if we are to, as Marxists notion, positively device change and with stand the universalizing inclination of capital. Money itself is "universal measure of value" (qtd. in Ritzer and Rayan 411) so General in this novel also values money over anything else "what's needed here isn't people but money" (The Autumn of the Patriarch 11).

Money as a value in capitalistic society and General is using it as a tool to satisfy himself "Capitalism" operates by producing an excess, a vicious circle of desire it satisfies more human needs than any other economy, but also creates more needs to be satisfied; creates more wealth but also more need to produce wealth"(Orford 109).General also at one part of the novel says "I'm not going to talk to poor people anymore" (The Autumn of the Patriarch 22). One of the reasons of General is that he thinks the nation collapse without him so he wanted to keep the country at any cost, whether it is disrespect of others.

Spivak talks about Socialism and capitalism both as elements which are in relation with imperialism; "One must pass through advanced capitalism in order to get to socialism" (The Post-Colonial Critic 110). As Spivak believes that capitalism is a gate for entering socialism, this notion is rejected throughout the novel, since in 
socialistic state, there is equality and the wealth is should be shared equally but we saw in the autumn of the patriarch that tyranny and oppression of the General is obstacle in reaching to such nation. The last materialistic part of the play which directly shows that money is power and everything is achievable by money is an utterance by General:

I [General] had to sign alone thinking mother of mine Bendición Alvarado no one knows better than you that it's better to be left without the sea than to allow a landing of marines, remember that they were the ones who thought up the orders they made me sign, they turned our artists into fairies, they brought the Bible and syphilis, they made people believe that life was easy, mother, that everything is gotten with money that blacks carry a contagion, they tried to convince our soldiers that the nation is a business and that the sense of honor is a bother invented by the government so that soldiers would fight for free, and it was to avoid the repetition of all those ills that I granted them the right to make use of our territorial waters in the way they considered best for the interests of humanity and peace among peoples. . .(The Autumn of the Patriarch 80)

The above paragraph is a dialogue of General when he confesses some of his wrong deeds and on that situation when he was about to die, he believes that it is better to lose the sea, which was the main reason that occupiers came to their country, rather than permitting them to come to the power and decide for their people. The occupiers also try to seduce the soldiers to believe that their nation is like merchandise as capitalists and could be sold, but the sense of honor and nationalism prevented them to do this; "Nationalism can only ever be a central political plan against oppression" (Spivak 1999). As General confesses the foreigners came to their country for the sake of humanity and peace but later he understood that their central goal was just to use their sources and to take the control of their country.

\section{Conclusion}

Gabriel Garcia Marquez was quite careful in choosing the events of the Autumn of the Patriarch. He successfully depicted the life of General who was similar to the real tyrant ruler of Caribbean Sea. The imperialistic part of this novel is also refers to the oppression and capitalism both practiced by its protagonist, General, who assumes himself as superior one and nothing is more important for him than money.This work is amongst the best works of the post-colonialism. This novel 
explored the devastating effects of power. It centers on a dictator who is the symbol of all other awful rulers who came to power all over the world after the end of colonialism. Various postcolonial themes were applicable including essentialism, marginality, oppression and capitalism as imperialistic one.By considering the postcolonial aspectsthroughSpivakian attitudes, this articleanalysed how author deals with identity and essentialism and in more specific manner the strategic essentialism which is used by margins of society who were women and those who were not entourage of the ruler, General. "Nationalism can only ever be a crucial political agenda against oppression" (A Critic of Postcolonial Reason 188).Generally it is concluded that where the margins of society who were especially women and those who were against the tyrant ruler, came to this conclusion that suppression of their needs are enough and they began to believe in themselves, tried to find their true place in society and united with each other, they were successful in pushing back the General who was symbol of other tyrants and oppressors around the world.

\section{References and notes:}

Anadon, J. (1989). The "Double" in Gabriel GarciaMárquez's The Autumn of the Patriarch. Indiana: Kellogg Institute.

Ashcroft, B.,Griffiths, G.,\& and Tiffin, H.(2007). Key Concepts in Post-colonial Studies $\left(2^{\text {nd }}\right.$ Ed.). New York: Routledge.

Bhalla, A.(1985).Power, Like a Desolating Pestilence: Dictatorship and Community in the Autumn of the Patriarch. Economic and Political Weekly 20.38: 1597-1600. Retrieved from JStor.Web. 〈http://www.jstor.org/stable/4374840>.

BookRags, Inc.(2016).The Autumn of the Patriarch Summary \& Study Guide. Retrieved from http://www.bookrags.com/studyguide-the-autumn-of-the-patriarch/\#gsc.tab=0.

Cartwright, R. L. (1968). Some Remarks on Essentialism.The Journal of Philosophy.65,615-626.

De Beauvoir, S. (1988). The Second Sex. London: Picador.

Eide, E. (2010). Strategic Essentialism and Ethnification Hand in Glove?Nordicom Review, $31,63-78$

Foucault, M. (1969).Archaeology of Knowledge. London: Routledge.

Marquez, G.G. (1975). The Autumn of the Patriarch.

Mishina, F. N. (2013).The Autumn of the Patriarch.Journal of Intercultural Disciplines.University of Hawaii at Hilo: Scarborough.

Narayan, U. (1998). Essence of Culture and a Sense of History: A Feminist Critique of Cultural Essentialism.Hypatia, 13(2), 86-106.

Orford, A. (2003).Reading Humanitarian Intervention.New York: Cambridge University Press. 
Phillips, A. (2010). What's Wrong with Essentialism?Distinction: Scandinavian Journal of SocialTheory, 11 (1), 47-60.

Ray, S. (2009).GayatriChakravortySpivak: In Other Words. Wiley: Wiley Blackwell.

Rafaty, R. (2014). GayatriSpivak on Recent Criticisms of Postcolonial Theory.Retrieved from http://www.cria.polis.cam.ac.uk/blog/?p=97.

Ritzer, G., Ryan, J.(2011).The Concise Encyclopedia of Sociology. (1st ed.). Wiley: WileyBlackwell.

Spivak, G.(1999). ACritique of Postcolonial Reason.United States of America: Harvard University.

---. (1990). The Post-Colonial Critic.New York\& London: Routledge.

---. (2012). In Other Worlds: Essays In Cultural Politics. New York\& London: Routledge.

---. (2008). Other Asias. Oxford: Blackwell.

Stone, P. H. (1981). The Paris Review, Gabriel GarcíaMárquez.The Art of Fiction 69. Retrieved fromhttp://www.theparisreview.org/interviews/3196/the-art-of-fiction-no69-gabriel-garcia-marquez>.

Williams, R. L. (1984).Gabriel GarcíaMárquez. Boston: Twayne Publishers. 


\title{
Summary
}

\section{Spivakian Concepts of Essentialism and Imperialism in Gabriel Garcia's "The Autumn of the Patriarch"}

\author{
Mohammad Motamedi \\ Golestan University, Iran
}

\author{
Abdolbaqi Rezaei Talarposhti \\ Golestan University, Iran \\ Behzad Pourqarib \\ Golestan University, Iran
}

In 1980, an Indian critic, Gayatri Chakravorty Spivak announced strategic essentialism as a major concept in postcolonial theory. It is a special form of essentialism which involves greater scopes of post-colonial studies such as subaltern, otherness, and strategic essentialism; this term can become meaningful in an imperialistic context where oppression and suppressions are as part of thecountry. With the increase of colonialism in nineteenth century and its consequences in twentieth century, which was almost the end of this era, many writers try to demonstrate it through literature. The mentioned concepts are traceable in countries which were experiencing the imperialism; then strategic essentialism helps the margins of society to find their true identity and by using it, they can survive. This paper is an attempt to represent essentialism and imperialism in Gabriel Garcia's The Autumn of the Patriarch. The findings of this paper may affect those countries which are still under the pressure of colonialism. The major conclusion is that if inferiors of the society unite with each other, find their true identity and stand against oppressions, then they can get rid of the oppressions.

Key Words: Post-colonial, Essentialism, Imperialism, Subaltern, Spivak, Oppression. 